\title{
Fluoroacetate Metabolism in Gloeocapsa sp. LB795 and its Relationship to Acetylene Reduction (Nitrogen Fixation)
}

\author{
By JOHN R. GALLON, M. IKRAM UL-HAQUE AND ALAN E. CHAPLIN \\ Department of Biochemistry, University College of Swansea, Singleton Park, \\ Swansea $S A 28 P P$
}

(Received 13 December 1977; revised 6 February 1978)

\begin{abstract}
Sodium fluoroacetate $(1 \mathrm{mM})$ caused an accumulation of citrate and altered the lipid composition in cells of Gloeocapsa sp. LB795. It also inhibited acetylene reduction (nitrogen fixation) by the alga - markedly under aerobic conditions, but much less so in the absence of oxygen. This inhibition is largely the result of the conversion of fluoroacetate to fluorocitrate which, by inhibiting aconitate hydratase (EC 4.2.1.3), interrupts the synthesis of the 2-oxoglutarate required for the assimilation of $\mathrm{NH}_{4}{ }^{+}$. The consequent accumulation of $\mathrm{NH}_{4}{ }^{+}$within the cells of Gloeocapsa sp. inhibits nitrogenase synthesis and, since oxygen rapidly inactivates pre-existing nitrogenase, nitrogen fixation by Gloeocapsa sp. decreases under aerobic conditions.
\end{abstract}

\section{INTRODUCTION}

Gloeocapsa sp. LB795 is a nitrogen-fixing, unicellular blue-green alga. Because it contains its nitrogen-fixing enzyme, nitrogenase, in the same undifferentiated cell as its photosynthetic apparatus, it seemed likely that the ATP and reducing power necessary to support nitrogen fixation might be supplied directly by photosynthesis. However, Gloeocapsa sp. continues to fix nitrogen, as measured by the acetylene reduction technique, when photosynthetic electron transport is inhibited by 3-(3,4-dichlorophenyl)-1,1-dimethylurea, suggesting that an alternative source of reducing power for nitrogen fixation might exist. In vitro studies indicated that this alternative source of reductant might be NADPH produced by isocitrate dehydrogenase (NADP+) (EC 1.1.1.42) (Gallon, Kurz \& LaRue, 1973). Furthermore, since $10 \mathrm{~mm}$-sodium fluoroacetate inhibited acetylene reduction by whole cells of Gloeocapsa sp. (Gallon, LaRue \& Kurz, 1975b), it seemed possible that isocitrate dehydrogenase might be a major source of reductant in vivo, even when photosynthesis was not inhibited.

However, this conclusion was based on the assumption that fluoroacetate inhibited acetylene reduction by depriving nitrogenase of reducing power. Thus, fluoroacetate was assumed to be converted to fluorocitrate which, in turn, inhibited aconitate hydratase (EC 4.2.1.3) and prevented the formation of isocitrate. In the absence of isocitrate, isocitrate dehydrogenase would not produce NADPH. Since it has not positively been demonstrated that fluoroacetate inhibits acetylene reduction in this manner, the aim of the present work was to examine the metabolism of fluoroacetate by Gloeocapsa sp. and the effect of this metabolism on acetylene reduction. 


\section{METHODS}

Growth of cultures. Gloeocapsa sp. LB795 (University of Texas Culture Collection) was grown in 151 of sterile medium free of combined nitrogen. The medium, which was a modification of ASM-1 medium (Gorham et al., 1964) had the following composition $\left(\mu \mathrm{mol} \mathrm{l}{ }^{-1}\right)$ : $\mathrm{NaCl}, 2000 ; \mathrm{MgSO}_{4}, 150 ; \mathrm{MgCl}_{2}, 145$; $\mathrm{CaCl}_{2}, 190 ; \mathrm{K}_{2} \mathrm{HPO}_{4}, 100 ; \mathrm{Na}_{2} \mathrm{HPO}_{4}, 100 ; \mathrm{FeCl}_{3}, 9 ; \mathrm{H}_{3} \mathrm{BO}_{3}, 6 ; \mathrm{MnCl}_{2}, 6 ; \mathrm{ZnCl}_{2}, 3 ; \mathrm{CoCl}_{2}, 0.08 ; \mathrm{CuCl}_{2}$, $0.0008 ; \mathrm{MoO}_{3}, 0.1 ; \mathrm{Na}_{2} \mathrm{EDTA}, 20$; and was adjusted to $\mathrm{pH} 7.5$ with solid $\mathrm{NaHCO}_{3}$. Conditions of growth were as previously described (Gallon, LaRue \& Kurz, 1972).

Enzyme assays. Nitrogen fixation by cultures of Gloeocapsa sp. $\left(0.2 \times 10^{8}\right.$ to $2 \times 10^{8}$ cells $\left.\mathrm{ml}^{-1}\right)$ was measured by the acetylene reduction technique after $4 \mathrm{~h}$ incubation with or without the addition of other compounds (Tözüm et al., 1977). Unless otherwise stated, assays were performed aerobically at $25^{\circ} \mathrm{C}$ under illumination at $2500 \mathrm{~lx}$.

Isocitrate dehydrogenase (NADP ${ }^{+}$) was assayed by the method of Ochoa (1955), using a broken cell preparation of Gloeocapsa sp. (Gallon et al., 1973).

${ }^{14} \mathrm{CO}_{2}$ fixation. Cells taken during the exponential phase of growth (up to $10 \mathrm{~d}$ after inoculation) were concentrated 20- to 50 -fold by settling under gravity. Samples $(1 \mathrm{ml})$ were then incubated, with or without $1 \mathrm{~mm}$-sodium fluoroacetate (Fluka, Buchs, Switzerland), for $4 \mathrm{~h}$ at $25^{\circ} \mathrm{C}$ and $2500 \mathrm{~lx}$ in sealed $7 \mathrm{ml}$ glass bottles. Sodium [ $\left.{ }^{14} \mathrm{C}\right]$ carbonate $\left(20 \mu \mathrm{Ci}\right.$; sp. act. 50 to $60 \mathrm{Ci} \mathrm{mol}^{-1}$; The Radiochemical Centre, Amersham) was then added and after another $1 \mathrm{~h}$ incubation, $1 \mathrm{ml}$ ethanol was added to prevent further reaction and also to disrupt the cells. Cell debris was removed by centrifugation and the ethanol-soluble products were separated and identified as described by Huggins (1966). The radioactivity in individual compounds was measured in a scintillation spectrophotometer after transferring radioactive spots from chromatographs to vials containing $20 \mathrm{ml}$ 2-(4'-tert-butylphenyl)-5-(4"-biphenylyl)-1,3,4-oxadiazole in toluene $\left(5 \mathrm{~g} \mathrm{l}^{-1}\right)$.

$\left[2 .{ }^{14} \mathrm{C}\right]$ Fluoroacetate metabolism. Cells were collected as described above and incubated for $4 \mathrm{~h}$ with $2.5 \mu \mathrm{Ci}$ sodium [2-14 C]fluoroacetate (sp. act. $10 \mathrm{Ci} \mathrm{mol}^{-1}$; ICN Corporation, Irvine, California, U.S.A.). Ethanol-soluble radioactive products were isolated, separated and identified as above or by chromatography in propanol/ammonia/water $(6: 3: 1$, by vol.) according to the method of Buffa, Peters \& Wakelin (1951). Lipids were extracted as described by Folch, Lees \& Sloane-Stanley (1957) after termination of the incubation by adding excess $(6 \mathrm{ml})$ methanol or 2-propanol. They were then separated, identified and their radioactivity was determined as described by Abreu-Grobois, Billyard \& Walton (1977).

Lipid synthesis. Cells collected as described above were incubated for $4 \mathrm{~h}$ with $2 \cdot 5 \mu \mathrm{Ci}$ sodium $\left[1-{ }^{14} \mathrm{C}\right]-$ acetate (sp. act. $57 \mathrm{Ci} \mathrm{mol}^{-1}$; The Radiochemical Centre) and with or without $1 \mathrm{~mm}$-sodium fluoroacetate. Lipids were then extracted, separated, identified and their radioactivity was determined as described by Abreu-Grobois et al. (1977).

\section{RESULTS AND DISCUSSION}

\section{Metabolism of fluoroacetate}

Cultures of Gloeocapsa sp. LB795 metabolize fluoroacetate only to a limited extent. The only ethanol-soluble product formed from [2-14 C]fluoroacetate was [14 C]fluorocitrate, and only $0.16 \%$ of the radioactivity added was found in this compound after $4 \mathrm{~h}$ incubation (Table 1). There was also an equivalent incorporation of radioactivity from $\left[2-{ }^{14} \mathrm{C}\right]$ fluoroacetate into the lipid of Gloeocapsa sp. Radioactivity was found in all the polar lipid fractions and analysis of their alkaline hydrolysis products showed that $70 \%$ of this radioactivity was located in their fatty acid moieties. The possible presence of fluorine in these lipids was not investigated.

The metabolism of fluoroacetate by Gloeocapsa sp. is therefore apparently simple. It is converted to fluorocitrate, presumably by enzymes of the tricarboxylic acid cycle; there is also some metabolism of fluoroacetate to fatty acids, though whether this involves a preliminary defluorination reaction is not known.

\section{Fluoroacetate and carbon metabolism}

Sodium fluoroacetate ( $1 \mathrm{mM}$ ) had no effect on photosynthetic oxygen evolution by Gloeocapsa sp., but increased the total incorporation of radioactivity from $\mathrm{Na}_{2}{ }^{14} \mathrm{CO}_{3}$. The radioactivity in identified individual ethanol-soluble products of ${ }^{14} \mathrm{CO}_{2}$ fixation increased by similar amounts, with the exceptions of citrate, in which radioactivity accumulated to a greater extent, and glutamate, in which a decreased incorporation of radioactivity was 


\section{Table 1. Metabolism of $\left[{ }^{14} \mathrm{C}\right]$ fluoroacetate by Gloeocapsa sp. LB795}

Cells were collected during the exponential phase of growth, concentrated and incubated aerobically at $25^{\circ} \mathrm{C}$ and $2500 \mathrm{~lx}$ for $4 \mathrm{~h}$ with $2 \cdot 5 \mu \mathrm{Ci} \mathrm{Na}\left[2-{ }^{14} \mathrm{C}\right]$ fluoroacetate. Ethanol-soluble radioactive products and lipid were isolated and identified as described in Methods.

Radioactive
product
Fluorocitrate
Total lipid
Lipid component
Origin
Sulpholipid
Phosphatidylglycerol
Digalactosyldiglyceride
Unidentified polar lipid
Monogalactosyldiglyceride
'Neutral lipid' (solvent front)

$\begin{array}{cc}\begin{array}{c}\text { Radioactivity } \\ \text { incorporated } \\ \text { [d.p.s. } \text { (ml cells) }^{-1} \text { ] }\end{array} & \text { \% incorporation } \\ 151 & 0 \cdot 16 \\ 167 & 0 \cdot 18 \\ & \\ 17 & \%(\mathrm{w} / \mathrm{w}) \text { of total lipid } \\ 18 & 10 \cdot 3 \\ 21 & 10 \cdot 7 \\ 15 & 12 \cdot 5 \\ 15 & 9 \cdot 1 \\ 48 & 8 \cdot 9 \\ 33 & 28 \cdot 7 \\ & 19 \cdot 8\end{array}$

Table 2. Incorporation of radioactivity from $\mathrm{Na}_{2}{ }^{14} \mathrm{CO}_{3}$ into citrate and glutamate by Gloeocapsa sp. LB795

Cells were collected during the exponential phase of growth, concentrated and incubated aerobically at $25^{\circ} \mathrm{C}$ and $2500 \mathrm{~lx}$ for $1 \mathrm{~h}$ with $20 \mu \mathrm{Ci} \mathrm{Na}{ }_{2}{ }^{14} \mathrm{CO}_{3}$ after $4 \mathrm{~h}$ preincubation with or without $\mathrm{Na}$ fluoroacetate $(1 \mathrm{~mm})$. Ethanol-soluble radioactive products were isolated and identified as described in Methods. The incorporation of radioactivity into ethanol-soluble products (in the absence of fluoroacetate) was $12 \cdot 8 \%$ of that added.

\begin{tabular}{lccc} 
& \multicolumn{2}{c}{ Radioactivity incorporated [d.p.s. (ml cells) ${ }^{-1}$ ] } & \\
Radioactive product & No addition & Na fluoroacetate & $\begin{array}{c}\% \text { of uninhibited } \\
\text { incorporation }\end{array}$ \\
Total incorporation & 94393 & 156691 & 166 \\
Citrate & 566 & 4273 & 755 \\
Glutamate & 7608 & 2920 & 38
\end{tabular}

found (Table 2). These observations are consistent with the view that in Gloeocapsa sp., as in many other organisms, fluoroacetate undergoes 'lethal synthesis' to fluorocitrate, which inhibits aconitate hydratase and blocks the metabolism of citrate to isocitrate, 2-oxoglutarate and glutamate (Buffa et al., 1951). In addition, the $\mathrm{NADP}^{+}$-dependent isocitrate dehydrogenase of Gloeocapsa sp. was also inhibited by fluorocitrate. In the presence of $0.35 \mathrm{~mm}$-fluorocitrate (equimolar with isocitrate), isocitrate dehydrogenase activity in cell extracts was $16 \%$ of that in the absence of inhibitors.

The incorporation of radioactivity into lipids from $\left[1-{ }^{14} \mathrm{C}\right]$ acetate was inhibited by $50 \%$ by $1 \mathrm{~mm}$-fluoroacetate (Table 3 ). This decrease is consistent with the effect of isotope dilution as the result of the metabolism of fluoroacetate into lipid, demonstrated above, although it is possible that fluoroacetate may inhibit some step in lipid biosynthesis. In contrast, however, fluoroacetate increased the accumulation of radioactivity into an unidentified polar lipid. Although the nature of this lipid is not known, it may be an alkalistable glycolipid which is occasionally found in extracts of Gloeocapsa sp. and which has an $R_{\mathrm{F}}$ value similar to that of the heterocyst cell wall glycolipid of Anabaena cylindrica. If so, it is possible that fluoroacetate stimulates the synthesis of a specific cell wall glycolipid. Such an increased synthesis could represent an early step in the response of Gloeocapsa sp. to unfavourable conditions. 


\section{Table 3. Effect of fluoroacetate on lipid synthesis by Gloeocapsa sp. LB795}

Cells were collected during the exponential phase of growth, concentrated and incubated aerobically at $25^{\circ} \mathrm{C}$ and $2500 \mathrm{~lx}$ for $4 \mathrm{~h}$ with $2 \cdot 5 \mu \mathrm{Ci} \mathrm{Na}\left[1{ }^{14} \mathrm{C}\right]$ acetate and, where indicated, Na fluoroacetate (1 mM). Lipids were extracted and identified as described by Abreu-Grobois et al. (1977). The incorporation of radioactivity into lipid (in the absence of fluoroacetate) was $6.0 \%$ of that added.

\begin{tabular}{|c|c|c|c|}
\hline & \multicolumn{2}{|c|}{ Radioactivity incorporated [d.p.s. $\left.\left.(\mathrm{ml} \mathrm{cells})^{-1}\right)\right]$} & \multirow{2}{*}{$\begin{array}{l}\% \text { of uninhibited } \\
\text { incorporation }\end{array}$} \\
\hline & No addition & $\mathrm{Na}$ fluoroacetate & \\
\hline Total lipid & 2219 & 1132 & 51 \\
\hline \multicolumn{4}{|l|}{ Lipid component } \\
\hline Origin & 202 & 38 & 19 \\
\hline Sulpholipid & 317 & 133 & 42 \\
\hline Phosphatidylglycerol & 601 & 247 & 41 \\
\hline Digalactosyldiglyceride & 337 & 121 & 36 \\
\hline Unidentified polar lipid & 109 & 336 & 308 \\
\hline Monogalactosyldiglyceride & 546 & 235 & 43 \\
\hline 'Neutral lipid' & 104 & 63 & 61 \\
\hline
\end{tabular}

\section{Table 4. Inhibition of acetylene reduction in Gloeocapsa sp. LB795 by fluoroacetate and related compounds}

Cells were collected during the exponential phase of growth and $50 \mathrm{ml}$ samples were incubated aerobically in $150 \mathrm{ml}$ Erlenmeyer flasks at $25^{\circ} \mathrm{C}$ and $2500 \mathrm{~lx}$ for $4 \mathrm{~h}$ with the compounds indicated. The flasks were then sealed, acetylene was added to $1 \%(\mathrm{v} / \mathrm{v})$ and after a further $1 \mathrm{~h}$ incubation the ethylene produced was measured by gas-liquid chromatography. The protein content of the cells was $0.098 \mu \mathrm{g}$ per $10^{8}$ cells.

The rates of acetylene reduction are typical but the values in parentheses, which show the rates as percentages of those in the absence of any additions, are the means of at least 20 observations.

Addition

None

$1 \mathrm{mM}-\mathrm{Na}$ fluoroacetate

1 mM-Na chloroacetate

$1 \mathrm{~mm}-\mathrm{Na}$ acetate

1 mM-Na fluoride

$1 \mathrm{~mm}-\mathrm{Na}$ fluoroacetate $+2 \mathrm{mM}-\mathrm{Na}$ acetate

$1 \mathrm{~mm}-\mathrm{Na}$ fluoroacetate $+5 \mathrm{mM}-\mathrm{CaCl}_{2}$

$1 \mathrm{~mm}-\mathrm{Na}$ fluoroacetate $+5 \mathrm{~mm}-\mathrm{MgCl}_{2}$
Acetylene reduction

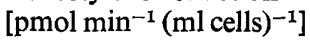

$$
\begin{gathered}
27 \cdot 0(100) \\
4 \cdot 6(17) \\
27 \cdot 0(100) \\
27 \cdot 3(101) \\
22 \cdot 1(82) \\
26 \cdot 2(97) \\
5 \cdot 7(21) \\
2 \cdot 4(9)
\end{gathered}
$$

The following compounds (at $2 \mathrm{~mm}$ ) were without significant effect in reversing the inhibition caused by $1 \mathrm{~mm}$-fluoroacetate, either in the presence or absence of $5 \mathrm{mM}^{-C_{a C l}}$ :acetamide, fumarate, glutamate, glycollate, glyoxylate, 2-hydroxyglutarate, isocitrate, malate, 2-oxoglutarate and pyruvate.

\section{Fluoroacetate and acetylene reduction}

Acetylene reduction by cultures of Gloeocapsa sp. in the exponential phase of growth (up to $10 \mathrm{~d}$ after inoculation) was completely inhibited after $4 \mathrm{~h}$ exposure to $10 \mathrm{~mm}$-fluoroacetate (Gallon et al., 1975b) and markedly inhibited by 1 mM-fluoroacetate (Tözüm et al., 1977). On the other hand, very old cultures of Gloeocapsa sp. (more than $17 \mathrm{~d}$ after inoculation) frequently showed less than a $50 \%$ inhibition of acetylene reduction by 1 mM-fluoroacetate. The effect of $1 \mathrm{~mm}$-fluoroacetate was similar whether cells were incubated in the light or in the dark.

The inhibition of acetylene reduction by fluoroacetate was specific since neither $1 \mathrm{mM}$ acetate nor $1 \mathrm{mM}$-chloroacetate inhibited acetylene reduction by Gloeocapsa sp. (Table 4). Furthermore, $1 \mathrm{~mm}$-sodium fluoride was only slightly inhibitory after $4 \mathrm{~h}$ incubation, suggesting that the effect of fluoroacetate was not caused by fluoride arising from any defluorination of the inhibitor.

Of the carbon compounds tested, only $2 \mathrm{mM}$-acetate prevented the inhibition caused by 
Table 5. Effect of various gas phases on acetylene reduction by Gloeocapsa sp. LB795 and the inhibition by fluoroacetate

Cells were incubated for $4 \mathrm{~h}$ under an atmosphere of the composition indicated and, where appropriate, with $\mathrm{Na}$ fluoroacetate $(1 \mathrm{~mm})$. Their ability to reduce acetylene was then measured as described in Table 4. The cells incubated under $\mathrm{CO}_{2}$-free air were previously suspended in medium adjusted to $\mathrm{pH} 7 \cdot 5$ with $\mathrm{NaOH}$ rather than $\mathrm{NaHCO}_{3}$. The protein content of the cells was $0 \cdot 116 \mu \mathrm{g}$ per $10^{8}$ cells.

The rates of acetylene reduction are typical; the percentages are the means of at least five observations.

\begin{tabular}{|c|c|c|c|}
\hline \multirow[b]{2}{*}{ Gas phase } & \multicolumn{2}{|c|}{ Acetylene reduction $\left[\mathrm{pmol} \mathrm{min}^{-1}(\mathrm{ml} \text { cells })^{-1}\right]$} & \multirow{2}{*}{$\begin{array}{l}\% \text { of uninhibited } \\
\text { activity }\end{array}$} \\
\hline & No addition & $\mathrm{Na}$ fluoroacetate & \\
\hline $\begin{array}{l}\text { Air } \\
\mathrm{N}_{2} \\
\mathrm{~N}_{2} / \mathrm{O}_{2}(0 \cdot 7: 0 \cdot 3, \mathrm{v} / \mathrm{v}) \\
\mathrm{Air} / \mathrm{CO}_{2}(0 \cdot 99: 0 \cdot 01, \mathrm{v} / \mathrm{v}) \\
\mathrm{CO}_{2} \text {-free air } \\
\mathrm{Ar} / \mathrm{O}_{2}(0 \cdot 8: 0 \cdot 2, \mathrm{v} / \mathrm{v})\end{array}$ & $\begin{array}{r}20 \cdot 4 \\
25 \cdot 7 \\
14 \cdot 1 \\
17 \cdot 3 \\
2 \cdot 9 \\
34 \cdot 3\end{array}$ & $\begin{array}{r}3 \cdot 5 \\
18 \cdot 4 \\
1 \cdot 4 \\
2 \cdot 8 \\
0 \cdot 1 \\
10 \cdot 3\end{array}$ & $\begin{array}{r}17 \\
72 \\
10 \\
16 \\
3 \\
30\end{array}$ \\
\hline
\end{tabular}

fluoroacetate (Table 4), presumably by competitively inhibiting the conversion of fluoroacetate to fluorocitrate. Acetamide, which was reported by Gitter (1956) to prevent the conversion of fluoroacetate to fluorocitrate in rats, was without effect on Gloeocapsa sp. Moreover, neither isocitrate nor 2-oxoglutarate reversed the inhibition of acetylene reduction by fluoroacetate, even though endogenous pools of these compounds in Gloeocapsa sp. would be depleted as a result of the inhibition of aconitate hydratase by fluorocitrate. However, isocitrate may be ineffective in reversing the inhibition because, as reported above, isocitrate dehydrogenase, as well as aconitate hydratase, was inhibited by fluorocitrate; and there is some doubt whether 2-oxoglutarate can enter the algal cells since exogenous 2-oxo[5-14 C]glutarate was apparently not metabolized by Gloeocapsa sp. (unpublished observations).

$\mathrm{CaCl}_{2}(5 \mathrm{~mm})$, but not $\mathrm{MgCl}_{2}$, slightly reversed the inhibition caused by fluoroacetate after $4 \mathrm{~h}$ (Table 4). Since citrate and other chelating agents inhibited acetylene reduction by Gloeocapsa sp. and their inhibitory effects were also reversed by $\mathrm{CaCl}_{2}$ but not by $\mathrm{MgCl}_{2}$, Tözüm et al. (1977) suggested that part of the inhibition caused by fluoroacetate may be the result of the observed accumulation of citrate in the algal cells.

Under anaerobic conditions, the inhibition of acetylene reduction by fluoroacetate was markedly reversed (Tözüm et al., 1977), though fluoroacetate metabolism was apparently unaffected since citrate still accumulated. However, on no occasion was it possible to demonstrate complete reversal of the inhibition of acetylene reduction by this means, even when photosynthetic oxygen evolution was inhibited by 3-(3,4-dichlorophenyl)-1,1-dimethylurea $(10 \mu \mathrm{M})$.

When cells of Gloeocapsa sp. were exposed to an increased concentration of oxygen, or when the $\mathrm{CO}_{2}$ concentration was decreased, acetylene reduction became more sensitive to inhibition by fluoroacetate (Table 5). Conditions of high oxygen or low $\mathrm{CO}_{2}$ concentration stimulate photorespiration, which, in the heterocystous blue-green alga Anabaena cylindrica, may compete with nitrogenase for reducing power (Lex, Silvester \& Stewart, 1972). In Gloeocapsa sp., acetylene reduction decreased under conditions which favour high rates of photorespiration (Table 5), consistent with competition between photorespiration and acetylene reduction in this organism also. If so, acetylene reduction by Gloeocapsa sp. was apparently more sensitive to competition from photorespiration in the presence of fluoroacetate than in its absence. A possible explanation for this is that fluoroacetate, by interrupting one source of reductant to acetylene reduction (NADPH from isocitrate dehydrogenase), has made the process more dependent upon alternative sources with which photorespiration may, perhaps, compete more efficiently. 
Table 6. Effect of $\mathrm{L}-$ methionine-DL-sulphoximine on acetylene reduction by Gloeocapsa sp. LB795 in the presence of fluoroacetate or $\mathrm{NH}_{4} \mathrm{Cl}$

Cells were collected, incubated for $4 \mathrm{~h}$ with the compounds shown and their ability to reduce acetylene was measured as described in Table 4. The protein content of the cells was $0 \cdot 103 \mu \mathrm{g}$ per $10^{8}$ cells.

The rates of acetylene reduction are typical, but the values in parentheses, which show the rates as percentages of those in the absence of any additions, are the means of at least 12 observations.

\begin{tabular}{|c|c|c|}
\hline Addition & [pmol min-1 & a cell \\
\hline $\begin{array}{l}\text { None } \\
2 \text { mM-methionine sulphoximine }\end{array}$ & $\begin{array}{l}19 \cdot 8 \\
17 \cdot 4\end{array}$ & $\begin{array}{l}(100) \\
(88)\end{array}$ \\
\hline 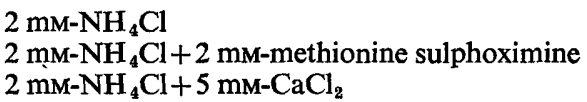 & $\begin{array}{r}5 \cdot 1 \\
12 \cdot 3 \\
8 \cdot 5\end{array}$ & $\begin{array}{l}(26) \\
(62) \\
(43)\end{array}$ \\
\hline $\begin{array}{l}1 \mathrm{~mm}-\mathrm{Na} \text { fluoroacetate } \\
1 \mathrm{~mm}-\mathrm{Na} \text { fluoroacetate }+2 \text { mM-methionine } \\
\text { sulphoximine }\end{array}$ & $\begin{array}{l}2 \cdot 2 \\
6 \cdot 1\end{array}$ & $\begin{array}{l}(11) \\
(31)\end{array}$ \\
\hline
\end{tabular}

However, if there were competition between nitrogenase and photorespiration for reducing power, conditions which decrease the level of photorespiration in Gloeocapsa sp. should increase the rate of acetylene reduction. Such conditions include atmospheres with a low concentration of oxygen or a high concentration of $\mathrm{CO}_{2}$. Whilst acetylene reduction was increased by a low concentration of oxygen, there was no stimulation under $0.01 \mathrm{~atm} \mathrm{CO}_{2}$ in air. Furthermore, fluoroacetate was no less inhibitory under air plus 0.01 atm $\mathrm{CO}_{2}$ than under air alone (Table 5). These observations suggest that photorespiration may not play a major role in the inhibition of acetylene reduction by fluoroacetate, though this cannot definitely be established in the absence of a demonstration that photorespiration in Gloeocapsa sp. is active in air and inhibited by $0.01 \mathrm{~atm} \mathrm{CO}_{2}$ in air.

Gloeocapsa sp. nitrogenase, the enzyme responsible for acetylene reduction, is rapidly inactivated by oxygen both in vitro and in vivo (Gallon, Kurz \& LaRue, 1975a). In Gloeocapsa sp., as in Anabaena flos-aquae (Bone, 1972), a constant level of nitrogenase activity may be maintained by a balance between synthesis and inactivation by oxygen. Hence, any compound which inhibits the synthesis of nitrogenase will, under an atmosphere containing oxygen, result in a decrease in nitrogenase activity. Such compounds include chloramphenicol, $\mathrm{NH}_{4} \mathrm{Cl}$ and, in view of its effects on acetylene reduction under air and under $\mathrm{N}_{2}$, possibly fluoroacetate (Tözüm et al., 1977). Furthermore, because fluoroacetate inhibited acetylene reduction less under $\mathrm{Ar} / \mathrm{O}_{2}(0 \cdot 8: 0 \cdot 2$, by vol.) than under air (Table 5), the conversion of $\mathrm{N}_{2}$ to $\mathrm{NH}_{4}{ }^{+}$, catalysed by nitrogenase, may be involved in fluoroacetate inhibition. Ammonium salts repress nitrogenase synthesis in nitrogen-fixing organisms and fluoroacetate would probably cause an accumulation of $\mathrm{NH}_{4}+$ in cells of Gloeocapsa sp. by interrupting the synthesis of 2-oxoglutarate which is required for the assimilation of newlyfixed $\mathrm{NH}_{4}{ }^{+}$. The effect of fluoroacetate on acetylene reduction by Gloeocapsa sp. could therefore be the result of an accumulation of $\mathrm{NH}_{4}{ }^{+}$to a repressive level for nitrogenase synthesis. Because no oxygen inactivation of pre-existing nitrogenase would occur under anaerobic conditions, an apparent reversal of this inhibition of acetylene reduction is observed under these conditions (Table 5).

Gloeocapsa sp. almost certainly assimilates the $\mathrm{NH}_{4}{ }^{+}$produced by nitrogen fixation by the pathway involving"glutamine synthetase (EC6.3.1.2) and glutamate synthase (EC2.6.1.53) though the Gloeocapsa sp. enzyme is ferredoxin-dependent rather than NADP+-dependent [see Miflin \& Lea (1976)]. L-Methionine-DL-sulphoximine (2 mM), an inhibitor of glutamine

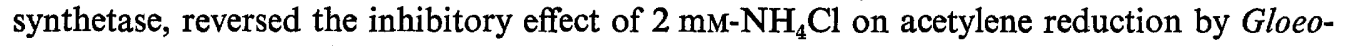
capsa sp. under aerobic conditions. In Gloeocapsa sp. therefore, as in $A$. cylindrica (Stewart \& Rowell, 1975), $\mathrm{NH}_{4}{ }^{+}$apparently does not inhibit nitrogenase synthesis directly; rather the inhibitor is, or is regulated by, a product of $\mathrm{NH}_{4}{ }^{+}$assimilation. The exact nature of this 
product has not been identified, though in $A$. cylindrica it may be carbamoyl phosphate (Stewart, Rowell \& Tel-Or, 1975). The addition of $0.5 \mathrm{~mm}$-carbamoyl phosphate to cultures of Gloeocapsa sp. inhibited acetylene reduction to $42 \%$ of its control level after $4 \mathrm{~h}$ aerobic incubation, but had virtually no effect under $\mathrm{N}_{2}$. It is therefore possible that carbamoyl phosphate may also be involved in the inhibition of nitrogenase synthesis in Gloeocapsa sp.

Whatever the mechanism, in Gloeocapsa sp. the inhibition of acetylene reduction by $\mathrm{NH}_{4} \mathrm{Cl}$ was reversed by methionine sulphoximine which also partially relieves the inhibition caused by fluoroacetate (Table 6), further implicating $\mathrm{NH}_{4}{ }^{+}$in this inhibition.

$\mathrm{CaCl}_{2}(5 \mathrm{~mm})$ partially reversed the inhibition of acetylene reduction by $\mathrm{NH}_{4} \mathrm{Cl}$ (Table 6) as well as that caused by fluoroacetate (Table 4). Therefore, the chelating agent which accumulates in the presence of fluoroacetate and inhibits acetylene reduction may not only be citrate. Others, perhaps linked to $\mathrm{NH}_{4}{ }^{+}$assimilation, may also cause part of the inhibition. In this context, the observation that the inhibition of acetylene reduction by $0.5 \mathrm{~mm}$ carbamoyl phosphate was also markedly reversed by $5 \mathrm{mM}-\mathrm{CaCl}_{2}$ may be significant.

In conclusion, fluoroacetate does not inhibit acetylene reduction by Gloeocapsa sp. solely by depriving nitrogenase of reductant generated by isocitrate dehydrogenase, as was first believed, though it is still possible that part of the inhibition might be exerted in this manner (Tözüm et al., 1977). Indeed, it appears that fluoroacetate does not inhibit acetylene reduction by any single mechanism. A major part of the inhibition is dependent upon oxygen and is most probably the result of the inhibition of nitrogenase synthesis. This could be caused directly or indirectly by $\mathrm{NH}_{4}{ }^{+}$which accumulates in the algal cells because fluoroacetate has interrupted the synthesis of the 2-oxoglutarate required for $\mathrm{NH}_{4}{ }^{+}$assimilation. A decrease in the ability of Gloeocapsa sp. to reduce acetylene would then be dependent upon the inactivation by oxygen of pre-existing nitrogenase. On the other hand, since Gloeocapsa sp. nitrogenase may be membrane-bound (Gallon et al., 1972) and fluoroacetate may inhibit the synthesis of lipids, which are major membrane components, it is possible that the oxygen-sensitive part of the fluoroacetate inhibition could result from a disruption of membranes by the inhibitor, thereby rendering nitrogenase more sensitive to oxygen inactivation. Furthermore, photorespiration might be involved in the oxygen-dependent part of the inhibition caused by fluoroacetate. The evidence presented here, however, favours the involvement of $\mathrm{NH}_{4}{ }^{+}$in this part of the inhibition rather than these alternative explanations.

A further part of the inhibition of acetylene reduction caused by fluoroacetate is reversed by $\mathrm{CaCl}_{2}$ and is distinct from the oxygen-dependent part of the inhibition since $\mathrm{CaCl}_{2}$ has the same effect in the absence of oxygen as in air. This part of the inhibition may result from an accumulation of chelating agents within cells of Gloeocapsa sp., caused by fluoroacetate. Citrate is probably one of these chelators, but there appear to be others also.

Thus, although the metabolism of fluoroacetate by Gloeocapsa sp. is limited, sufficient fluorocitrate is formed to inhibit aconitate hydratase. This inhibition then results in a dramatic decrease in the ability of the alga to fix nitrogen but the mechanism by which nitrogen fixation is inhibited is more complex than has previously been suggested.

The contributions of Mr T. Billyard, Mr A. Kumar and Miss D. Tözüm to this work are gratefully acknowledged. The authors also thank Miss J. Link for her skilled technical assistance and Dr T. J. Walton for his help and advice in connection with lipid metabolism in Gloeocapsa sp.

\section{REFERENCES}

Abreu-Grobois, F. A., Billyard, T. C. \& Walton, T. J. (1977). Biosynthesis of heterocyst glycolipids of Anabaena cylindrica. Phytochemistry 16, 351354.

BONE. D. H. (1972). The influence of canavanine, oxygen and urea on the s eady-state levels of nitrogenase in Anabaena flos-aquae. Archiv für Mikrobiologie 86, 13-24.

Buffa, P., Peters, R. A. \& Wakelin, R. W. (1951). Biochemistry of fluoroacetate poisoning. Isolation 
of an active tricarboxylic acid fraction from poisoned kidney homogenates. Biochemical Journal 48, 467-477.

Folch, J., LeEs, M. \& Sloane-Stanley, G. H. (1957). A simple method for the isolation and purification of total lipids from animal tissues. Journal of Biological Chemistry 226, 497-509.

Gallon, J. R., LaRue, T. A. \& KuRz, W. G. W. (1972). Characteristics of nitrogenase activity in broken cell preparations of the blue-green alga Gloeocapsa sp. LB 795. Canadian Journal of Microbiology 18, 327-332.

Gallon, J. R., Kurz, W. G. W. \& LaRue, T. A. (1973). Isocitrate supported nitrogenase activity in Gloeocapsa sp. LB 795. Canadian Journal of Microbiology 19, 461-465.

Gallon, J. R., Kurz, W. G. W., \& LaRue, T. A. $(1975 a)$. The physiology of nitrogen fixation by a Gloeocapsa sp. In Nitrogen Fixation by Freeliving Microorganisms, International Biological Programme, vol. 6, pp. 159-173. Edited by W. D. P. Stewart. Cambridge: Cambridge University Press.

Gallon, J. R., LaRue, T. A. \& Kurz, W. G. W. $(1975 b)$. Nitrogen fixation and photosynthesis in a unicellular blue-green alga. Phytochemistry 14, 861.

GITTER, S. (1956). The influence of acetamide on citrate accumulation and fluoroacetate poisoning. Biochemical Journal 63, 182-187.

Gorham, P. R., McLachlan, J. S., Hammer, U. T. \& KIM, W. K. (1964). Isolation and culture of toxic strains of Anabaena flos-aquae (Lyngb.) de Bréb. Verhandlungen der Internationalen Vereinigung für theoretische und angewandte Limnologie 15, 796-804.

HugGins, A. K. (1966). Intermediary metabolism in Carcinus maenas. Comparative Biochemistry and Physiology 18, 283-290.

LeX, M., Silvester, W. B. \& Stewart, W. D. P. (1972). Photorespiration and nitrogenase activity in the blue-green alga Anabaena cylindrica. Proceedings of the Royal Society B 180, 87-102.

Miflin, B. J. \& LeA, P. J. (1976). The pathway of nitrogen assimilation in plants. Phytochemistry 15, 873-885.

OсноA, S. (1955). Isocitric dehydrogenase system (TPN) from pig heart. Methods in Enzymology 1, 699-704.

Stewart, W. D. P. \& Rowell, P. (1975). Effects of L-methionine-DL-sulphoximine on the assimilation of newly fixed $\mathrm{NH}_{3}$, acetylene reduction and heterocyst production in Anabaena cylindrica. Biochemical and Biophysical Research Communications 65, 846-856.

Stewart, W. D. P., Rowell, P. \& Tel-Or, E. (1975). Nitrogen fixation and the heterocyst in blue-green algae. Biochemical Society Transactions 3, 357-361.

Tözüm, D., ul-HaQue, M. I., Chaplin, A. E. \& GalloN, J. R. (1977). The effect of fluoroacetate on acetylene reduction by Gloeocapsa. Biochemical Society Transactions 5, 1482-1484. 